DOI: 10.20472/EFC.2020.014.013

\author{
TAMARA SLIŠKOVIĆ \\ Faculty of Economics and Business, University of Zagreb, Croatia \\ TOMISLAV SEKUR \\ Faculty of Economics and Business, University of Zagreb, Croatia
}

\title{
THE CALCULATION OF REGIONAL INDEX OF DWELLING PRICES IN CROATIA
}

\begin{abstract}
:
In the existing literature in the field of housing economics, great attention has been paid to modeling housing prices. Residential property prices are generally very important indicator as they may indicate developments in the local economy. Moreover, many existing research have proven that there is a strong interdependence of the movement of housing prices with economic developments. Therefore, different market participants (home owners, potential buyers, lessors, tenants etc.), as well as subjects from broader economic environment (banks, local government, researchers etc.) are interested in trends on housing market, and in particular in housing prices. For that reason, constant improvement of housing prices statistics is very important for all mentioned entities.

In Croatia, the issue of housing prices has become topical in the last 15 years due to the turbulent developments in the domestic housing market. Generally, the indicator which is most available to the general public is average price which is published by real estate agencies and advertisers. Such indicator fails to reflect real prices movements since it encompasses the difference in quality of the offered/sold housing units on the market. The more reliable indicator would be one that is "cleared" form the impact that qualitative characteristics of the housing unit have on its price. The most commonly used method for constructing such price indicators is hedonic approach. Hedonic indices provide information about real change in the price between two points of time. The methodology of calculation hedonic housing price index in Croatia has advanced significantly over the last 12 years. In this research we use hedonic model approach to calculate the index of dwelling prices for Croatia, as well as for four regions (The City of Zagreb, Middle and South Adriatic, Istria and North Adriatic and the region Other). The variables which are included in the model are price of the dwelling, location, floor area, number of rooms, the construction year and time of sale. Two different indices based on asked and realized prices are calculated within this research. The comparison between calculated indices shows that there are large price differences between geographically different Croatian dwelling markets.
\end{abstract}

Acknowledgment: This work has been supported by the Croatian Science Foundation under the project no. 6785 .

\section{Keywords:}

Housing Price Index, Dwelling, Hedonic Estimation, Multiple Regression Analysis, Croatian Housing Market

JEL Classification: R21, R31, 018 


\section{Introduction}

The housing market is a very important segment of the national economy. As housing is one of the fundamental human needs, many individuals are interested in developments in the local housing market. The group of interested entities includes house owners, potential buyers, tenants, renters, but also subjects from the broader economic environment, like local authorities and tax policymakers. In the first place, all mentioned subjects are interested in the movements of the housing prices. Housing prices can be expressed in different forms (average prices, median prices), but there are also specific indicators which are often observed in a housing market analyses. These indicators are usually price indexes which are calculated under a specific methodology for the purpose of monitoring real trends in the housing market. For that reason, constant improvement of statistical methods for estimating housing prices is very important for all interested entities. Among the different methods which are used in the calculation of the housing price indicators, the hedonic pricing method is particularly prominent.

One of the main characteristics of real estate is heterogeneity, which is the basis for application of hedonic approach in calculating real estate price indexes. In a housing market, heterogeneity of housing units is strongly expressed. Every housing unit is different and specific. Moreover, there are no two identical housing units. They differ in many characteristics, primarily by location. Location characteristics may include the position of the property in a specific region or in a particular part of the city. Location can also be observed through neighbourhood characteristics which can include the presence of different amenities or some measure of the environmental quality. Many existing research have shown that location is a significant determinant of housing prices on particular markets. In addition to location, there are also qualitative characteristics which can determine the price of the specific housing unit. The group of internal characteristics can include numerous characteristics, such as floor area, number of rooms, bathrooms, interior design and equipment, exterior appearance, energy performance etc. Every of these mentioned characteristics has some contribution in shaping overall price of particular housing unit. This fact is the basis for the application of the hedonic pricing models.

The hedonic approach is based on the premise that each characteristic of the housing property brings a certain degree of satisfaction to the user. In other words, each of mentioned characteristics has its own, so-called implicit price which can be estimated in hedonic models. The sum of the market prices of separate components of a residential unit then represents its total market price (McDonald and McMillen, 2007). By using hedonic method, it is possible to construct a quality-adjusted housing price index.

The methodology of calculation hedonic housing price indexes in Croatia has advanced significantly over the last 12 years. The main goal of this research is to provide new index for specific regions, which has not been calculated before. In this paper we use hedonic model approach to calculate the index of dwelling prices for overall Croatia, as well as for four regions (The City of Zagreb, Middle and South Adriatic, Istria and North Adriatic and the region Other). Observing price movements in particular regions aims to highlight the differences that exist within the national housing market. Furthermore, we tried to point out the difference between asked and realized dwelling prices by calculating two different indexes for each region. 
The organization of this paper is as follows. In section 2 theoretical background for conducting this research is provided. Section 3 describes data and methodology. The empirical results and discussion are presented in section 4. The final section is conclusion in which are summarized main findings, research limitations and recommendations for further investigation in this field.

\section{Theoretical background}

In general, the application of hedonic models is not limited to the housing market only. They can be used to determine the price of any complex good. The hedonic method dates back to Court (1939) who used it to calculate automobile price indexes. Although his research can be observed as pioneering hedonic price analysis, this method has been popularized by Zvi Grilliches in the early 1960s. Grilliches (1961) also applied this approach within the car industry although he used more sophisticated statistical methods than his predecessor. Several years after, authors like Lancaster (1966) and Rosen (1974) laid down the conceptual foundations for this method. Hedonic models can be used also in the environmental field (Bayer, Keohane and Timmins, 2009) or to calculate quality-adjusted price index for any complex product (for example, computers like in Berndt, Grilliches and Rappaport (1995)). But, the widest application of these model has been found in the papers which deal with housing market issues.

Within the housing market, there are 3 purposes of using hedonic pricing models. These are, according to Hill (2011), the following:

1. Constructing a hedonic housing price index, which does not reflect changes in quality of housing units over time;

2. Enabling automatic assessment of the value of housing units using the estimated implicit prices and

3. Explaining variations in housing prices and determining price effects of changes in certain neighborhood characteristics, such as local taxes, school availability, crime rates, etc.

The application of the hedonic method to the housing market is extremely complex, for the reason that residential real estate is an example of an extremely differentiated product. The heterogeneity of the housing market implies that each property on the market is special and there are no two identical units. There is a number of characteristics according to which residential real estate differs. Moreover, the list of variables that could have significant effects on the residential property price is practically non-exhaustive. In general, the characteristics of housing can be classified into two groups:

- Physical or internal characteristics, such as number of rooms, number of bathrooms, living space, external and internal appearance, the year of building, etc.

- Locational characteristics which include the geographical coordinates of residential real estate or the location of the unit in a particular part of the city or in a particular region. It can also include different measures of distances, like distances from the city center, business centers or local amenities such as schools, parks, health centers, etc. This group also observes other neighborhood characteristics, such as environmental quality, crime rates etc.

In practice, the selection of variables which will be included in certain model depends primarily on the specifics of the housing market for which the research is conducted, but also on the availability of data. For this reason, it is impossible to define a universal set of variables that would be applicable in all examples. One step towards this, however, is Sirmans et al. (2006) citing nine internal characteristics that most commonly appear in housing price modeling. 
These are in order: living space, land area, age of the property, number of bedrooms, bathrooms, existence of a garage, swimming pool, fireplace and air conditioning. The type of residential property (house, dwelling etc.) can also be added to this list. Also, numerous existing studies have shown that location is the factor that most strongly determines the price of housing.

The general way to calculate hedonic implicit prices is to set up the regression model in which housing price represents dependent variable and its characteristics independent ones. The existing research shows that exponential function is most commonly used. In other words, model is often set up in a semilogarithmic form as follows:

$$
\ln P=\beta_{0}+\beta_{1} X_{1}+\beta_{2} X_{2}+\cdots+\beta_{n} X_{n}+\varepsilon
$$

In equation 1, $P$ represents the housing price vector, while $X_{n}$ represents vector of characteristics that can be grouped by different criteria, for example location, qualitative, socio-economic, etc. According to McDonald and McMillen (2007), this form of model generally describes data better than a linear model, and it has been applied in numerous analyzes (for example see Yiu and Tam, 2004; Zietz, Zietz and Sirmans, 2008; Ottensmann, Payton and Man, 2008; Keskin, 2008).

The main reason for calculating hedonic housing price index is the fact that large number of real estate market analyzes use average or median prices as an indicator of market developments. Such indicators are not able to eliminate the bias in the data which occurs if an unusually large number of above-average or below-average quality real estate was sold in a certain period. In other words, such price measures are not adjusted for the quality of real estate. The quality adjustment is necessary to observe the "pure" change in residential real estate prices between the two periods and that is achieved by applying the hedonic method. There are several methods of calculation hedonic price index. Hill (2011) gives a taxonomy of hedonic price indexes for housing and briefly describes five methods of calculation:

- Time-dummy methods

- Imputation methods

- Characteristics index methods

- Nonparametric methods

- Repeat sales and hedonic hybrid methods

In Croatia, there are only few authors which used hedonic method in housing market analyzes. Botrić and Kordej de Villa (2005) used hedonic modelling approach to investigate regional differences in the housing market in Croatia. In their research location is defined as a location of the residential unit in a specific county. In the domestic literature in the field of hedonic modelling, a special place belongs to the paper of Kunovac et al. (2008). This research represents a special contribution to Croatian statistics, since it presents a methodological frame for the construction of an econometric model for the calculation of the first domestic housing price index that takes into account both the price and the characteristics of residential property. Their hedonic real estate price index (HREPI) was regularly published by Croatian National Bank statistics until 2015, in which Croatian Bureau of Statistics starts to publish house price index $(\mathrm{HPI})$, which becomes the main indicator of house prices movements. It is important to point out that Kunovac et al. (2008) also approximated location by a specific region, county, or part of the city. In their research, location is included in hedonic model as a binary variable, just like most of observed internal characteristics. Beside location, authors observed price effects of living area (in square meters) and internal characteristics 
such as number of rooms, the year of construction, the time of sale, the type of real estate, the existing of the balcony, telephone, heating type etc. Their index was calculated on a national basis, as well as for four regions (The City of Zagreb, Adriatic, Other-Urban and Other-Rural). The methodology of construction of more sophisticated hedonic index (HPI) is presented in Kunovac and Kotarac (2019). Unlike HREPI, which was based on the data obtained from the Croatian Real Estate Exchange, house price index (HPI) is based on the data of the Tax Administration of the Republic of Croatia and is constructed in cooperation between the Croatian Bureau of Statistics (CBS) and the Croatian National Bank (CNB). The model of Kunovac and Kotarac observes the set of the minimum required characteristics which include the location of residential property, the time of sale, the year of construction, the type of residential property (house or flat), the floor area and the price. To define the location, the the territory of the Republic of Croatia was divided into three strata/regions (the City of Zagreb, the Adriatic Coast and Other). Additional location variables were also included in the models by dividing Adriatic and Other regions to the smaller units (municipalities and cities).

More precise definition of location is found in the papers of Slišković and Tica. In their research, location is defined through different measures of distance from the city center. Their earlier paper from 2016 represents the first domestic research in which spatial distances and travelling times are implemented in hedonic model. Along with distance measures, authors have also used "standard" definition of location, i.e. location in certain city parts and zones in the form of binary variables. The aim of their research was to investigate the effects of distance from the city center on the prices of dwellings in the City of Zagreb. However, their model can hardly be considered as a "standard" hedonic model, since it does not include the internal characteristics of residential properties. That is the main deficiency of the mentioned research, which is eliminated in their later study. In the 2019, Slišković and Tica have constructed one comprehensive hedonic model for the market of dwellings in Zagreb, which observes effects of different location measures as well as internal characteristics of residential property to its price.

Following and combining the mentioned approaches of hedonic modelling in Croatia, in this paper we estimate hedonic regressions which will serve as a basis for a calculation new hedonic price indexes for whole Croatia and specific parts of Croatia. On the one hand, we follow the standard strategy of dividing Croatia to regions. But, unlike previous research, we separated the Adriatic region to two strata (Middle and South Adriatic, Istria and North Adriatic) which represent meaningful whole due to the geographical and other peculiarities. Observing price movements in particular regions aims to highlight the differences that exist within the national housing market. Moreover, we calculate two types of indexes (index of asked and index of realized prices) using time-dummy method, as it is presented in Kunovac et al. (2008).

\section{Data and Methodology}

The econometric analysis conducted in this paper is based on a database that was purchased from the Croatian Real Estate Exchange, for the purpose of this research. The database contains basic information on dwellings that were advertised and sold on the teritory of Croatia in the period from 2010-2019, and which the Real Estate Exchange has in its records. The main disadvantage of the database is that the quality of data collected by the Real Estate Exchange has declined over time. Specifically, significantly less data on real estate characteristics has been collected in recent years than was in the first period of observing. 
Furthermore, information on certain characteristics is not available for all markets. For example, we were not able to define location in terms of distances because information on precise location (i.e.adress of the dwelling) was available only for the market of Zagreb and very small number of other Croatian cities. For the rest, the only available information about the location was the county in which dwelling is located. Therefore, the main deficiency of the database is the large number of missing observations. The low quality of the data is also the main limitation of this research.

In its original form, the database contains data on the location (county, or part of the city in the Case of Zagreb), the asked and realized prices, the time of sale, floor area, floor on which the apartment is located, total number of floors, the year of construction, orientation and the number of rooms. Due to the relatively small number of existing observations, we dropped information about orientation, floor and total number of floors in the building. For every dwelling in the sample is the information about asked price (per square meter), but the information about realized price exists only for some dwellings. Database covers information about dwellings located in 15 Croatian counties (including the City of Zagreb)

Available data are included in the hedonic model as numerical or indicator (binary/dummy) variables, depending on the nature of the feature. Data on the prices per square meter of the dwelling (both asked and realized), floor area and number of rooms were entered into the model in numerical form. Other variables are converted into an indicator variables that describe the existence of a certain characteristic. The most complex issue was forming the location variable for each of four covered regions.

The City of Zagreb, as one observed region, was divided to 14 districts in order to assess the impact of the location on the dwelling prices within hedonic model. Table 1 presents used location variables along with number of observations for each district.

Table 1: Districts of Zagreb (division for the purpose of the research)

\begin{tabular}{|c|c|c|c|c|}
\hline Variable & DMAKSIMIR & DNZISTOK & DNZZAPAD & DPESCENICA \\
\hline Observations & 284 & 152 & 195 & 250 \\
\hline Description & Maksimir & $\begin{array}{c}\text { Novi Zagreb- } \\
\text { East }\end{array}$ & $\begin{array}{c}\text { Novi Zagreb- } \\
\text { West }\end{array}$ & Pešćenica \\
\hline Variable & DMEDVESCAK & DZAPAD & DPODSLJEME & DOSTALO \\
\hline Observations & 210 & 348 & 118 & 53 \\
\hline Description & Gornji grad i Medveščak & West & Podsljeme & Other \\
\hline Variable & DTRESNJEVKASJEVER & DTRNJE & DDONJIGRAD & DDUBRAVA \\
\hline Observations & 405 & 194 & 412 & 114 \\
\hline Description & Trešnjevka North & Trnje & Donji grad & Dubrava \\
\hline Variable & DTRESNJEVKAJUG & DCRNOMEREC & & \\
\hline Observations & 300 & 302 & & \\
\hline Description & Trešnjevka South & Črnomerec & & \\
\hline
\end{tabular}

Source: authors 
In the Middle and South Adriatic region, the location variable has four modalities, as region covers four counties (Table 2):

Table 2: The division of Middle and South Adriatic region to counties

\begin{tabular}{|c|c|c|c|c|}
\hline Variable & SIBKNIN & SPLITDAL & ZAD & DUBNER \\
\hline Observations & 130 & 325 & 129 & 180 \\
\hline Description/County & Šibensko-Kninska & $\begin{array}{c}\text { Splitsko- } \\
\text { Dalmatinska }\end{array}$ & Zadarska & $\begin{array}{c}\text { Dubrovačko- } \\
\text { Neretvanska }\end{array}$ \\
\hline
\end{tabular}

Source: authors

The principle of dividing region to counties to precisely define location was also applied for the Istria and North Adriatic region and Other region (see Tables 3 and 4).

Table 3: The division of Istria and North Adriatic region to counties

\begin{tabular}{|c|c|c|c|}
\hline Variable & IST & PRIMGOR & LICSENJ \\
\hline Observations & 295 & 46 & 30 \\
\hline Description/County & Istarska & $\begin{array}{c}\text { Primorsko- } \\
\text { Goranska }\end{array}$ & $\begin{array}{c}\text { Ličko- } \\
\text { Senjska }\end{array}$ \\
\hline
\end{tabular}

Source: authors

Table 4: The division of Other region to counties

\begin{tabular}{|c|c|c|c|c|}
\hline Variable & KRAZAG & BJELBIL & KARL & ZAGR \\
\hline Observations & 24 & 168 & 27 & 61 \\
\hline Description & Krapinsko-Zagorska & $\begin{array}{c}\text { Bjelovarsko- } \\
\text { Bilogorska }\end{array}$ & Karlovačka & Zagrebačka \\
\hline Variable & OSBAR & VUKSRIJ & VAR & \\
\hline Observations & 26 & 2 & 14 & \\
\hline Description & Osječko-Baranjska & $\begin{array}{c}\text { Vukovarsko- } \\
\text { Srijemska }\end{array}$ & Varaždinska & \\
\hline
\end{tabular}

Source: authors

As it is visible from presented tables, the most expressed market activity was recorded in Zagreb. Higher number of transacted dwellings is presented also in the Middle and South Adriatic and counties Istarska and Bjelovarsko-Bilogorska. In other counties was recorded really small number of transactions in covered ten-year period.

The variable year of the construction was transformed also to a binary variable called "newbuilt". We constructed it to take value 1 if dwelling was sold in the year of construction, or if it was sold at the latest two years after construction. In the opposite, the dwelling has not been considered as a newly built, so it takes a value 0 .

The most important variable for this research is time of sale. We converted this variable to a dummy variable that reflects the year in which the property was sold. Therefore, the variable has 10 modalities, for each year in the covered period. This variable is valuable for this research as its estimation represents a basis for deriving hedonic price index. Unfortunately, due to the small number of observation in most counties, we were not able to construct a variable which reflects quarter in which dwelling is sold. In other words, there was large number of quarters in which there was no transactions at all in some counties. Therefore, we observe transactions on the yearly basis, so hedonic price index will be calculated for certain years as well. 
Our hedonic model is set up as a standard hedonic model in which dependent variable is natural logarithm of price per square meter, while independent variables are levels. General form of our model is similar to those presented in Kunovac et al. (2008) and Slišković and Tica (2019). It has the following form:

$$
\ln p_{j, i}=\alpha+\sum_{j=1}^{m-1} \beta_{j} X_{i j}+\sum_{j=1}^{l} \gamma_{j} W_{i j}+\sum_{j=2}^{T} \delta_{j} D_{i j}+\varepsilon_{i,} \quad i=1,2, \ldots, N
$$

The dependent variable has two modalities-asked price (P1) and realized price (P2). $X_{j}$ represents a vector of locational dummy variables for individual districts or counties, every of $\mathrm{m}$ modalities. As the regression contains intercept, in order to avoid dummy variable trap, we included m-1 modalities on the right side of the equation. In that case, the effect of the dropped (based) modality is captured in the constant of the regression. The estimated parameters of other m-1 modalities then represent relative differences to the base one, which is interpreted through constant term. If the parameter by the certain dummy variable is assessed as statistically significant, it does not mean that certain modality is significant in the model at a certain level of significance, but that the coefficient is significantly different from the base modality coefficient (Wooldridge, 2013).

$W_{i j}$ represents a matrix of variables that describe the qualitative characteristics of dwellings, and includes $l$ characteristics. Finally, $D_{i j}$ represents the time indicator of a variable with $\mathrm{T}$ modalites. As our time dimension is represented by years, $T=10$. As in the case of location, one of the modalities is omitted here as well, which will be contained in the constant term. In order to make interpretation of parameters simpler, we omitted the first observed year, so that the other estimated parameters reflect the differences in relation to first observed period.

After estimating the parameters of the variables that represent the sale periods, the next step is converting them into price indexes. As there are several methods to achieve this, we decided to follow the approach proposed by Kunovac et al. (2008), who used the time-dummy method to calculate the hedonistic real estate price index. According to Hill (2011), this method is considered to be the original hedonic method and is usually used when the hedonic model has a semilogarithmic functional form. If the general form of the model is as follows:

$$
y=Z \beta+D \delta+\varepsilon
$$

where $D$ represents a matrix of dummy variables for time periods, it is pretty simple to construct price index $P_{t}$. Indexes for certain periods are obtained by exponentiating the estimated parameters, denoted here by $\hat{\delta}_{t}$ :

$$
\hat{P}_{t}=\exp \left(\hat{\delta}_{t}\right)
$$




\section{Results of empirical analysis}

In the first stage of the research, the hedonic model for the whole of Croatia was assessed. We defined location as a dummy variable with four modalities, representing the four regions covered. Also, a sufficient number of observations allowed us to construct a hedonic index on a quarterly frequency. The estimated model in the following form:

$$
\begin{gathered}
\ln P=\beta_{0}+\beta_{1} \text { MIDSOUTH_ADRIA }+\beta_{2} \text { ISTRIANORTH }+\beta_{3} \text { OTHER }+\beta_{4} M 2+\beta_{5} \text { ROOMS } \\
+\beta_{6} N E W B U I L T+\sum_{j=2}^{39} \delta_{j} D_{j}+\varepsilon
\end{gathered}
$$

$\boldsymbol{D}_{\boldsymbol{j}}$ represents a vector of time variables, i.e. the quarters in which dwelling is sold. As it is already mentioned, the variable $P$ is expressed in two modalities:

$$
P=\left\{\begin{array}{c}
P 1 \text { (asked prices }) \\
P 2(\text { realized prices }
\end{array}\right\}
$$

The base modality, in terms of location, is the Zagreb region. Its effect on house prices is captured in the constant term of the regression. All equations are estimated using OLS. The

\begin{tabular}{|c|c|c|c|}
\hline \multicolumn{2}{|c|}{ DEPENDENT VARIABLE: logP1 } & \multicolumn{2}{|c|}{ DEPENDENT VARIABLE: $\log P 2$} \\
\hline Variable & Coefficient & Variable & Coefficient \\
\hline $\mathrm{C}$ & $7,49^{* * *}$ & $\mathrm{C}$ & $7,44^{* * *}$ \\
\hline MIDSOUTH_ADRIA & $0,12^{* * *}$ & MIDSOUTH_ADRIA & $0,13^{* * *}$ \\
\hline ISTRIANORTH & $-0,07^{* * *}$ & ISTRIANORTH & $-0,07^{\star \star \star}$ \\
\hline OTHER & $-0,53^{* * *}$ & OTHER & $-0,53^{* * *}$ \\
\hline M2 & $0,00^{* *}$ & M2 & 0,00 \\
\hline ROOMS & $0,03^{* * *}$ & ROOMS & $0,01^{* * *}$ \\
\hline NEWBUILT & $0,07^{* * *}$ & NEWBUILT & $0,07^{* * *}$ \\
\hline $2010 \mathrm{Q} 2$ & $-0,04^{*}$ & $2010 \mathrm{Q} 2$ & $-0,05$ \\
\hline $2010 \mathrm{Q} 3$ & $-0,07^{* * *}$ & $2010 \mathrm{Q3}$ & $-0,10^{\star \star \star}$ \\
\hline $2010 \mathrm{Q} 4$ & $-0,06^{\star * \star}$ & $2010 \mathrm{Q} 4$ & $-0,07^{* *}$ \\
\hline $2011 \mathrm{Q} 1$ & $-0,09^{* * *}$ & $2011 \mathrm{Q} 1$ & $-0,12^{* * *}$ \\
\hline $2011 Q 2$ & $-0,09^{* * *}$ & $2011 \mathrm{Q} 2$ & $-0,13^{\star \star \star}$ \\
\hline 2011Q3 & $-0,08^{\star * \star}$ & $2011 \mathrm{Q} 3$ & $-0,09^{* *}$ \\
\hline 2011Q4 & $-0,11^{* * *}$ & 2011Q4 & $-0,09^{* *}$ \\
\hline 2012Q1 & $-0,02$ & $2012 Q 1$ & $-0,08^{* *}$ \\
\hline 2012Q2 & $-0,10^{* *}$ & 2012Q2 & $-0,02$ \\
\hline 2012Q3 & $-0,17^{* \star \star}$ & 2012Q3 & $-0,21^{* * *}$ \\
\hline $2012 Q 4$ & $-0,12^{* * *}$ & $2012 Q 4$ & $-0,10^{\star \star \star}$ \\
\hline $2013 Q 1$ & $-0,15^{\star \star \star}$ & $2013 \mathrm{Q} 1$ & $-0,16^{\star * *}$ \\
\hline 2013Q2 & $-0,23^{* * *}$ & $2013 Q 2$ & $-0,26^{\star * *}$ \\
\hline 2013Q3 & $-0,19^{* * *}$ & $2013 Q 3$ & $-0,26^{\star * *}$ \\
\hline
\end{tabular}
results of estimation are presented in Table 5.

Table 5: The results of the estimated hedonic model for Croatia 


\begin{tabular}{|c|c|c|c|}
\hline $2013 Q 4$ & $-0,21^{\star * *}$ & 2013Q4 & $-0,26^{* * *}$ \\
\hline 2014Q1 & $-0,19^{* * *}$ & 2014Q1 & $-0,22^{* * *}$ \\
\hline 2014Q2 & $-0,24^{\star * *}$ & 2014Q2 & $-0,28^{* * *}$ \\
\hline 2014Q3 & $-0,20^{\star * *}$ & 2014Q3 & $-0,20^{\star * \star}$ \\
\hline 2014Q4 & $-0,16^{\star \star \star}$ & 2014Q4 & $-0,15^{\star \star \star}$ \\
\hline 2015Q1 & $-0,24^{* * *}$ & 2015Q1 & $-0,22^{\star \star *}$ \\
\hline 2015Q2 & $-0,20^{\star * *}$ & 2015Q2 & $-0,21^{\star * \star}$ \\
\hline 2015Q3 & $-0,28^{* * *}$ & 2015Q3 & $-0,30^{\star * *}$ \\
\hline 2015Q4 & $-0,24^{* * *}$ & 2015Q4 & $-0,25^{\star * \star}$ \\
\hline 2016Q1 & $-0,30^{* * *}$ & 2016Q1 & $-0,28^{\star * *}$ \\
\hline 2016Q2 & $-0,29^{* * *}$ & 2016Q2 & $-0,27^{* * *}$ \\
\hline 2016Q3 & $-0,32^{* * *}$ & 2016Q3 & $-0,35^{\star * *}$ \\
\hline 2016Q4 & $-0,30^{\star * *}$ & 2016Q4 & $-0,27^{\star \star *}$ \\
\hline 2017Q1 & $-0,14^{\star * *}$ & 2017Q1 & $-0,09^{* \star *}$ \\
\hline 2018Q1 & $-0,07$ & 2018Q1 & $-0,03$ \\
\hline 2018Q2 & $-0,29^{\star * *}$ & 2018Q2 & $-0,17^{\star \star}$ \\
\hline 2018Q3 & $-0,34^{\star * \star}$ & 2018Q3 & $-0,36^{\star * \star}$ \\
\hline 2018Q4 & $-0,20^{* * *}$ & 2018Q4 & $-0,12^{* *}$ \\
\hline 2019Q1 & $-0,16$ & 2019Q1 & $-0,12^{*}$ \\
\hline 2019Q2 & $-0,10^{* *}$ & 2019Q2 & $-0,06$ \\
\hline 2019Q3 & $-0,07$ & 2019Q3 & $-0,09$ \\
\hline R-squared & 0,346 & R-squared & 0,290 \\
\hline \multicolumn{2}{|c|}{ Included observations: 4670} & \multicolumn{2}{|c|}{ Included observations: 3616} \\
\hline \multicolumn{2}{|c|}{$\begin{array}{l}\text { White heteroskedasticity-consistent } \\
\text { standard errors \& covariance }\end{array}$} & & \\
\hline
\end{tabular}

Source: authors' calculation

Note: Asterisks indicate a rejection of the null hypothesis $(\beta=0)$ at a significance level of $1 \%\left({ }^{*} * *\right), 5 \%$ $\left(^{*}\right)$ and $10 \%\left(^{*}\right)$

On the one hand, estimation of hedonic model for the whole Croatia provides results which can be assessed as satisfactory. Estimated parameters are mainly statistically significant. But, on the other hand, there is not a good fit in observed models. That implies that some of the important determinants of dwelling prices are obviously omitted in our model and that is the consequence of the low-quality database. Despite the fact that estimated models result with low goodness-of-fit measures, the most of obtained results are in line with our expectations. Firstly, it is clear that dwelling prices in the Middle and South Adriatic region are significantly higher in relation to Zagreb (which is set up as a base modality). This can be explained due to the high demand for second homes, which is generated from domestic, but also from foreign subjects. In other regions, that is not the case. In terms of internal characteristics, it is clear that newly built properties have statistically higher price per square meter comparing to older ones. Estimation of the parameters of the time dummy variables provides a foundation for constructing hedonic price indexes for asked and realized prices in Croatia on a quarterly basis. One deficiency was the lack of the observations in period from second to last quarter in 2017, so that observations are calculated using log-linear interpolation in EViews. The values of obtained indexes are presented in Table 6, and graphically presented in Graph 1 below. From the mentioned Graph, it is visible that there were no significant differences in 
movements of asked and realized prices. In other words, it seems that expectations of sellers were pretty good adopted to buyers' expectations.

Table 6: The calculation of hedonic index of dwelling prices in Croatia

\begin{tabular}{|c|c|c|c|c|c|}
\hline QUARTER & HICRO(P1) & HICRO(P2) & QUARTER & HICRO(P1) & HICRO(P2) \\
\hline Q1_10 & 100,00 & 100,00 & Q1_15 & 78,92 & 80,22 \\
\hline Q2_10 & 96,30 & 100,00 & Q2_15 & 81,62 & 81,26 \\
\hline Q3_10 & 93,60 & 90,58 & Q3_15 & 75,41 & 73,80 \\
\hline Q4_10 & 94,05 & 93,53 & Q4_15 & 78,31 & 78,01 \\
\hline Q1_11 & 91,20 & 88,36 & Q1_16 & 73,98 & 75,34 \\
\hline Q2_11 & 91,34 & 87,57 & Q2_16 & 74,48 & 76,62 \\
\hline Q3_11 & 91,96 & 91,20 & Q3_16 & 72,53 & 70,30 \\
\hline Q4_11 & 89,83 & 91,21 & Q4_16 & 74,36 & 76,16 \\
\hline Q1_12 & 100,00 & 92,37 & Q1_17 & 87,01 & 91,48 \\
\hline Q2_12 & 90,53 & 100,00 & Q2_17 & 90,09 & 93,54 \\
\hline Q3_12 & 84,65 & 80,71 & Q3_17 & 93,28 & 95,64 \\
\hline Q4_12 & 88,63 & 90,44 & Q4_17 & 96,58 & 97,80 \\
\hline Q1_13 & 86,00 & 84,89 & Q1_18 & 100,00 & 100,00 \\
\hline Q2_13 & 79,09 & 76,90 & Q2_18 & 74,83 & 84,61 \\
\hline Q3_13 & 82,94 & 77,21 & Q3_18 & 71,36 & 69,79 \\
\hline Q4_13 & 80,83 & 77,37 & Q4_18 & 82,03 & 88,35 \\
\hline Q1_14 & 82,32 & 80,12 & Q1_19 & 100,00 & 88,51 \\
\hline Q2_14 & 78,88 & 75,84 & Q2_19 & 90,57 & 100,00 \\
\hline Q3_14 & 81,98 & 81,81 & Q3_19 & 100,00 & 100,00 \\
\hline Q4_14 & 84,87 & 85,70 & & & \\
\hline
\end{tabular}

Source: authors' calculation

Graph 1:Hedonic index of dwelling prices in Croatia

\section{HICRO}

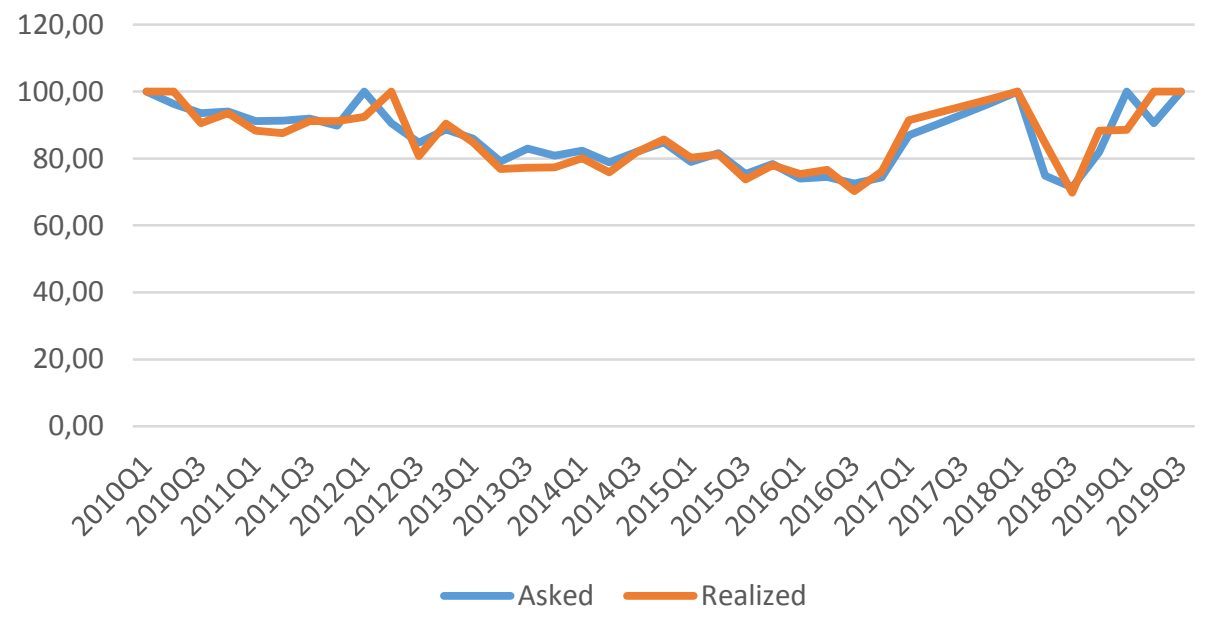

Source: authors' calculation

The estimation of hedonic model for Zagreb (Table 7) results with higher value of coefficient of determination compared with previous estimate for Croatia. As estimated coefficients are 
mainly statistically significant, model can be assessed as satisfactory. Results show that prices of dwelling in Zagreb are, in average, highest in the downtown of Zagreb (which is approximated with the district Donji Grad, which is chosen to be base modality). The exception is only Medveščak and Gornji grad, in which asked prices are statistically higher than in downtown. As in the previous estimate, new built is a characteristic which positively affects the dwelling prices per square meter. A slightly surprising result is that the size of the apartment does not affect its price. This result can also be found in some previous research, like Slišković and Tica (2019).

Hedonic price indexes for Zagreb on the quarterly basis are graphically presented in Graph 2. It should also be emphasized that observations for the period 2017q2-2017q4 were not available in the original database, so we calculated missing values using log-linear interpolation in EViews.

Table 7: The results of the estimated hedonic model for Zagreb

\begin{tabular}{|c|c|c|c|}
\hline \multicolumn{2}{|c|}{ DEPENDENT VARIABLE: $\log P 1$} & \multicolumn{2}{|c|}{ DEPENDENT VARIABLE: $\log P 2$} \\
\hline Variable & Coefficient & Variable & Coefficient \\
\hline C & $7,75^{\star \star \star}$ & C & $7,68^{* * *}$ \\
\hline DCRNOMEREC & $-0,20^{\star \star \star}$ & DCRNOMEREC & $-0,20^{\star \star *}$ \\
\hline DDUBRAVA & $-0,38^{* * *}$ & DDUBRAVA & $-0,36^{* \star *}$ \\
\hline DMAKSIMIR & $-0,11^{\star \star \star}$ & DMAKSIMIR & $-0,13^{\star \star *}$ \\
\hline DMEDVESCAK & $0,05^{\star *}$ & DMEDVESCAK & 0,00 \\
\hline DNZISTOK & $-0,42^{* * *}$ & DNZISTOK & $-0,40^{\star * *}$ \\
\hline DNZZAPAD & $-0,33^{\star \star *}$ & DNZZAPAD & $-0,38^{\star \star \star}$ \\
\hline DPESCENICA & $-0,26^{\star * *}$ & DPESCENICA & $-0,25^{\star \star \star}$ \\
\hline DPODSLJEME & $-0,15^{\star \star *}$ & DPODSLJEME & $-0,19^{* \star *}$ \\
\hline DTRESNJEVKAJUG & $-0,26^{\star * *}$ & DTRESNJEVKAJUG & $-0,22^{* * *}$ \\
\hline DTRESNJEVKASJEVER & $-0,26^{* \star \star}$ & DTRESNJEVKASJEVER & $-0,25^{\star \star \star}$ \\
\hline DTRNJE & $-0,16^{* * *}$ & DTRNJE & $-0,16^{\star \star *}$ \\
\hline DZAPAD & $-0,38^{\star \star \star}$ & DZAPAD & $-0,36^{\star * \star}$ \\
\hline DOSTALO & $-0,64^{* \star *}$ & DOSTALO & $-0,64^{* \star *}$ \\
\hline M2 & 0,00 & M2 & 0,00 \\
\hline ROOMS & $0,01^{* *}$ & ROOMS & 0,00 \\
\hline NEWBUILT & $0,10^{\star \star *}$ & NEWBUILT & $0,11^{* * *}$ \\
\hline 2010Q2 & $-0,03^{*}$ & 2010Q2 & $-0,05^{\star \star *}$ \\
\hline 2010Q3 & $-0,06^{\star \star \star}$ & 2010Q3 & $-0,11^{* \star *}$ \\
\hline 2010Q4 & $-0,06^{* \star *}$ & $2010 Q 4$ & $-0,07^{\star \star \star}$ \\
\hline 2011Q1 & $-0,06^{\star * *}$ & 2011Q1 & $-0,11^{* \star *}$ \\
\hline 2011Q2 & $-0,06^{\star * *}$ & 2011Q2 & $-0,11^{\text {***}}$ \\
\hline 2011Q3 & $-0,10^{\star \star \star}$ & $2011 Q 3$ & $-0,11^{\star \star \star}$ \\
\hline 2011Q4 & $-0,12^{\star \star *}$ & 2011Q4 & $-0,10^{\star \star *}$ \\
\hline 2012Q1 & $-0,06^{* *}$ & $2012 Q 1$ & $-0,12^{\star \star \star}$ \\
\hline 2012Q2 & $-0,01$ & $2012 Q 2$ & 0,04 \\
\hline 2012Q3 & $-0,13^{\star * *}$ & 2012Q3 & $-0,12^{\star \star \star}$ \\
\hline 2012Q4 & $-0,14^{\star \star \star}$ & $2012 Q 4$ & $-0,12^{\star \star \star}$ \\
\hline 2013Q1 & $-0,11^{\star \star \star}$ & 2013Q1 & $-0,13^{\star * \star}$ \\
\hline 2013Q2 & $-0,23^{\star \star \star}$ & 2013Q2 & $-0,29^{* \star *}$ \\
\hline
\end{tabular}




\begin{tabular}{|c|c|c|c|}
\hline $2013 Q 3$ & $-0,20^{\star * *}$ & $2013 Q 3$ & $-0,32^{\star \star *}$ \\
\hline $2013 Q 4$ & $-0,21^{\star \star \star}$ & $2013 Q 4$ & $-0,30^{\star \star *}$ \\
\hline 2014Q1 & $-0,18^{* * *}$ & 2014Q1 & $-0,21^{* * *}$ \\
\hline 2014Q2 & $-0,26^{\star \star *}$ & 2014Q2 & $-0,29^{* * *}$ \\
\hline 2014Q3 & $-0,27^{\star \star \star}$ & 2014Q3 & $-0,26^{\star * *}$ \\
\hline 2014Q4 & $-0,26^{\star * *}$ & 2014Q4 & $-0,25^{* * *}$ \\
\hline 2015Q1 & $-0,21^{\star * *}$ & $2015 Q 1$ & $-0,19^{* * *}$ \\
\hline $2015 Q 2$ & $-0,29^{* * *}$ & 2015Q2 & $-0,29^{* * *}$ \\
\hline 2015Q3 & $-0,33^{\star * *}$ & $2015 Q 3$ & $-0,35^{* * *}$ \\
\hline $2015 Q 4$ & $-0,36^{\star * *}$ & 2015Q4 & $-0,35^{* * *}$ \\
\hline 2016Q1 & $-0,29^{\star \star \star}$ & 2016Q1 & $-0,26^{\star * *}$ \\
\hline 2016Q2 & $-0,33^{\star \star *}$ & 2016Q2 & $-0,32^{\star \star *}$ \\
\hline 2016Q3 & $-0,32^{\star \star \star}$ & 2016Q3 & $-0,35^{\star \star *}$ \\
\hline 2016Q4 & $-0,31^{\star * *}$ & 2016Q4 & $-0,25^{\star * *}$ \\
\hline 2017Q1 & $-0,23^{\star \star *}$ & 2017Q1 & $-0,17^{\star * *}$ \\
\hline $2018 Q 1$ & $-0,09$ & $2018 Q 1$ & $-0,04$ \\
\hline 2018Q2 & $-0,25^{\star * *}$ & 2018Q2 & $-0,24^{* * *}$ \\
\hline _2018Q3 & $-0,29^{* * *}$ & 2018Q3 & $-0,27^{\star *}$ \\
\hline 2018Q4 & $-0,14^{\star \star *}$ & 2018Q4 & $-0,09^{\star *}$ \\
\hline 2019Q1 & $-0,01$ & 2019Q1 & 0,04 \\
\hline 2019Q2 & $-0,08$ & 2019Q2 & $-0,03$ \\
\hline 2019Q3 & $-0,02$ & 2019Q3 & $-0,02$ \\
\hline R-squared & 0,45 & R-squared & 0,41 \\
\hline Included observations: 3219 & & Included observations: 2165 & \\
\hline \multicolumn{2}{|c|}{$\begin{array}{l}\text { White heteroskedasticity-consistent standard } \\
\text { errors \& covariance }\end{array}$} & \multicolumn{2}{|c|}{$\begin{array}{l}\text { White heteroskedasticity-consistent } \\
\text { standard errors \& covariance }\end{array}$} \\
\hline
\end{tabular}

Source: authors' calculation

Graph 2:Hedonic index of dwelling prices in Croatia

\section{HIZG}

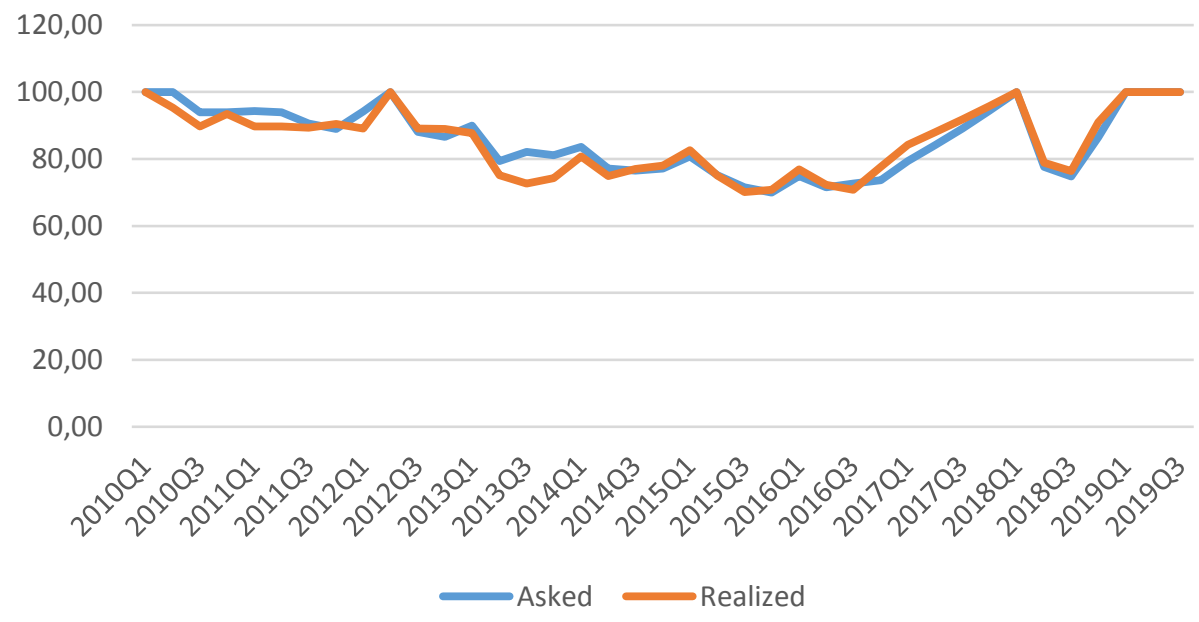

Source: authors' calculation 
All conclusions for the region of Zagreb are in line with those for Croatia. In observed period, asked prices do not show significant deviations from those achieved. It is also visible that price movements in Zagreb have generally followed national trends in dwelling prices. Concretely, it is visible that real estate crisis, that has started in 2008 and manifested in price decline, lasted until 2016, when dwelling prices begin to rise. With some oscillations in last periods, it can be generally concluded that the prices at the end of 2019 have reached the level which has been recorded in the beginning of the observed period.

In the second stage of research, we estimated hedonic models for four defined region. In this case, we were not able to calculate indexes on a quarterly basis, as there was relatively small number of observations recorded in certain regions. Therefore, we calculated indexes on a yearly basis. The values of the hedonic dwelling index for Zagreb (HIZG), Middle and South Adriatic (HIMS), Istria and North Adriatic (HIIN) and Other region (HIOTH) are presented in a Table 8 . The results of estimation of original models for regions, which are base for calculating these indexes, are provided in Appendix. All estimations of the models are done in the EViews.

Table 8: Hedonic dwelling price indexes in Croatian regions

\begin{tabular}{|c|c|c|c|c|c|c|c|c|}
\hline YEAR & HIZG (P1) & HIZG (P2) & HIMS(P1) & HIMS(P2) & HIIN(P1) & HIIN(P2) & HIOTH(P1) & HIOTH(P2) \\
\hline Y2010 & 100,00 & 100,00 & 100,00 & 100,00 & 100,00 & 100,00 & 100,00 & 100,00 \\
\hline Y2011 & 95,71 & 94,77 & 100,00 & 100,00 & 100,00 & 100,00 & 100,00 & 100,00 \\
\hline Y2012 & 94,08 & 94,32 & 90,01 & 83,63 & 78,48 & 79,82 & 90,02 & 90,78 \\
\hline Y2013 & 85,34 & 82,48 & 80,65 & 77,23 & 73,38 & 69,57 & 100,00 & 100,00 \\
\hline Y2014 & 81,38 & 82,03 & 83,93 & 80,10 & 85,12 & 83,32 & 100,00 & 84,71 \\
\hline Y2015 & 80,23 & 82,28 & 77,48 & 76,88 & 78,21 & 77,50 & 100,00 & 86,98 \\
\hline Y2016 & 76,59 & 80,48 & 92,48 & 100,00 & 68,65 & 69,53 & 86,96 & 84,48 \\
\hline Y2017 & 82,57 & 88,78 & 90,98 & 100,00 & 100,00 & 100,00 & 100,00 & 100,00 \\
\hline Y2018 & 89,86 & 100,00 & 100,00 & 100,00 & 55,57 & 60,86 & 100,00 & 100,00 \\
\hline Y2019 & 100,00 & 100,00 & 67,29 & 68,43 & 59,53 & 61,61 & 100,00 & 87,89 \\
\hline
\end{tabular}

Source: authors' calculation

The comparison between specific regions shows the significant differences in price developments (see Figure 1). As already mentioned, the most stable trends, without significant oscillations, are present in the Zagreb dwelling market. The movement of estimated indexes in Zagreb is in accordance with trends at a dwelling market, as well as with the overall macroeconomic trends in Croatia. Significant oscillations are noticeable in other regions. While in Zagreb the prices in 2019 reached the levels of 2010, the coastal regions experienced a significant decrease in dwelling prices at the end of the observed period. The strongest decline of both asked and realized dwelling prices is present in Istria and North Adriatic region, but it should be noted that in the entire observed period, the both measures of prices oscillated equally, without large mutual deviations. In the Middle and South Adriatic region the price recovery after 2015 is recorded (as happened in Zagreb), but in the last observed year this market experiences a big price drop. It is particularly interesting that the realized prices remained at unchanged stable levels for three years (2016-2018), after which they fell significantly, together with the asking prices. 
Trends in the region Other could be assessed as fairly stable and without turbulent swings. The Figure 1 shows that this market experienced a decrease in the realized dwelling prices until 2016, while the asked prices have been mostly unchanged. This is also noticeable in the last observed year, when realized prices fell while the asked remained at a stable level from 2010. But it should also be noted that the smallest share of transactions was recorded in this segment of national market. A larger number of dwelling sales (168) were recorded in only one, Bjelovarsko-Bilogorska County. On the other hand, that number can be considered as quite small when we take into account that it is realized in ten-year period. For this reason, it can be considered that price stability in this region is rather the result of low market activity and a small number of transactions.

The differences in dwelling price movement in four observed regions are illustrated in Figure 2. Regional differences in dwelling price trends are clearly visible here, especially the magnitude of the recent fall in dwelling prices in the Adriatic region compared to Zagreb. The same trend are presented when observing asked, as well as realized prices.

Figure 1: The hedonic price indexes of dwelling prices in Croatian regions

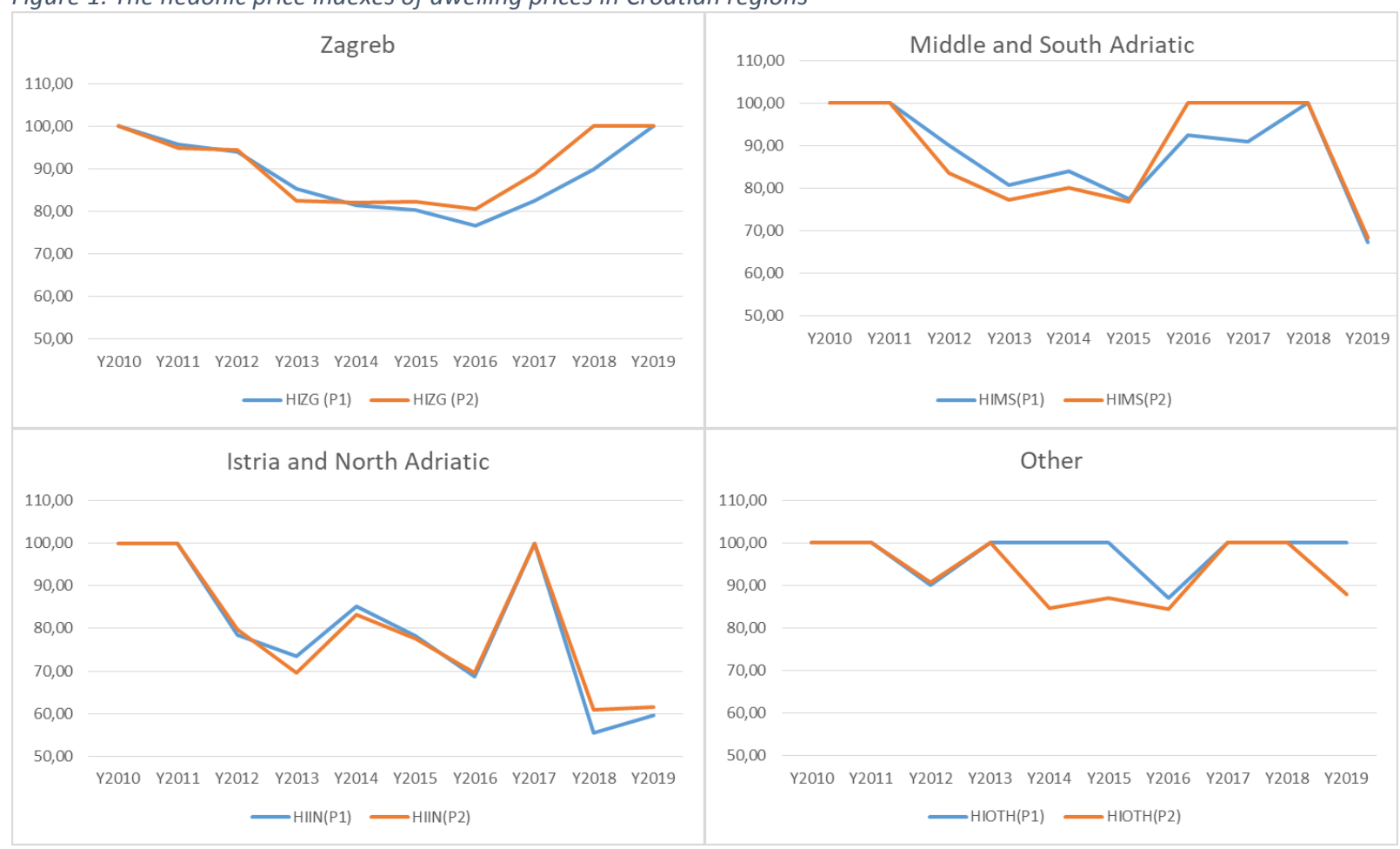

Source: authors' calculation 
Figure 2: The comparison od hedonic price indexes of $d$ welling prices between Croatian regions
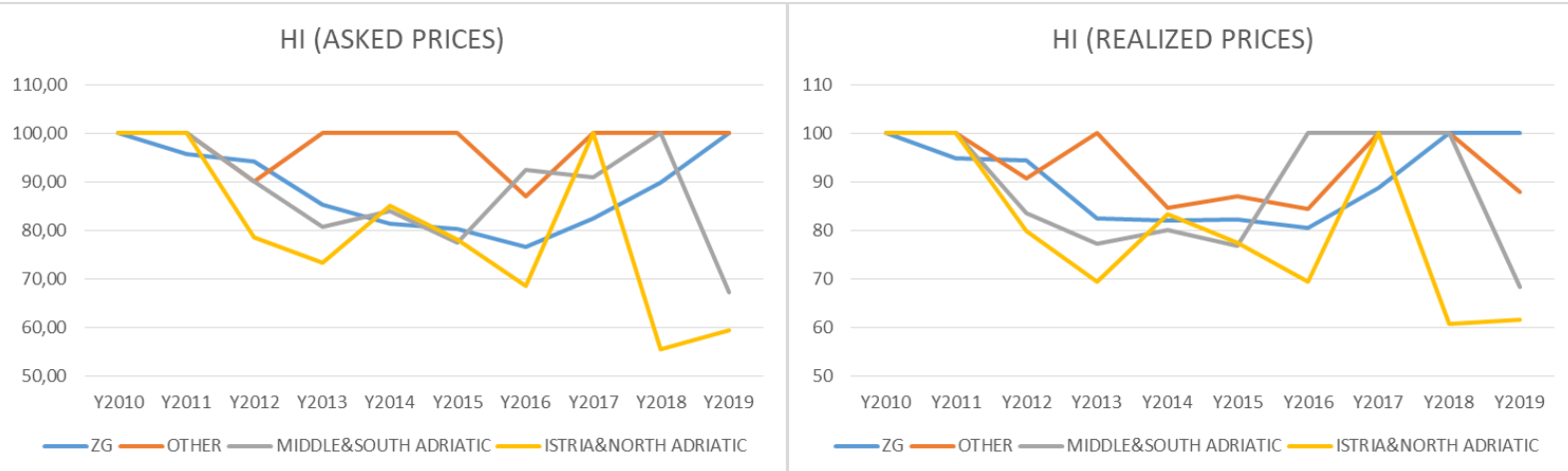

Source: authors' calculation

\section{Conclusion}

This research represents a small contribution to the housing prices statistics in Croatia. The hedonic price modelling in Croatia became topical in last 12 years, but relatively small number of domestic authors dealt with this issue. Although there are already comprehensive methodological frames for calculating hedonic indexes of residential prices, as well as indexes which are published in regular statistic, we wanted to make a contribution by providing the new index for specific regions, which has not been calculated before. Concretely, we calculate the index of dwelling prices for overall Croatia, as well as for four regions (The City of Zagreb, Middle and South Adriatic, Istria and North Adriatic and the region Other). Unlike previous research, we separated the Adriatic region to two strata (Middle and South Adriatic, Istria and North Adriatic) which represent meaningful whole due to the geographical and other peculiarities. We also take into account the differences between asked and realized prices of dwellings, so we calculate two different indexes for each region.

The analysis conducted in this research lies on the data obtained by the Real Estate Exchange. The database contains information about prices and characteristics of dwellings in Croatia which are sold in the period 2010-2019. The main limitation of this research is the quality of database. Generally, the quality of data collected by the Real Estate Exchange has declined over time. Specifically, significantly less data on real estate characteristics has been collected in recent years than was in the first period of observing. Furthermore, information on certain characteristics is not available for all markets. For example, we were not able to define location in terms of distances because information on precise location (i.e. address of the dwelling) was available only for the market of Zagreb and very small number of other Croatian cities. For the rest, the only available information about the location was the county in which dwelling is located. Therefore, the main deficiency of the database is the large number of missing observations.

Estimation of hedonic models and construction of the regional indexes of dwelling prices clearly shows that there are significant differences in price developments between regions. The most stable trends, without significant oscillations, are present in the Zagreb dwelling market. The movement of estimated indexes in Zagreb is in accordance with trends at a dwelling market, as well as with the overall macroeconomic trends in Croatia. Significant oscillations are noticeable in other regions. While in Zagreb the prices in 2019 reached the levels of 2010, the coastal regions experienced a significant decrease in dwelling prices at the 
end of the observed period. Trends in the region Other could be assessed as fairly stable and without turbulent swings. The same conclusions are made when observing asked, as well as realized prices.

While it is obvious that there are significant differences in regional housing markets, all conclusions should be drawn with caution. Primarily, a poor input database does not allow the development of more comprehensive models. This shortcoming is manifested in the relatively small values of the coefficients of determination in the estimated models. Larger number of data on the characteristics of dwellings, and in particular the availability of data by which the location could be precisely defined, would certainly contribute to a better quality of model assessment. This would also allow us to draw more precise and accurate conclusions. 


\section{References}

- Bayer P. N. Keohane and C. Timmins (2009). Migration and Hedonic Valuation: The Case of Air Quality. Journal of Environmental Economics and Management 58(1), 114.

- Berndt E. R., Z. Griliches, and N. J. Rappaport (1995). Econometric Estimates of Price Indexes for Personal Computers in the 1990s. Journal of Econometrics 68, 243268.

- Botrić, V. and Kordej De Villa, Ž. (23.-27- kolovoz 2005.). Determinants of regional housing market in Croatia. 45th Congress of the European Regional Science Association. Amsterdam.

- Court, A. T. (1939). Hedonic Price Indexes with Automotive Examples. U The Dynamics of Automobile Demand (str. 99-117). New York: The General Motors Corporation.

- Griliches, Z. (1961). Hedonic Price Indexes for Automobiles: An Econometric of Quality Change. The Price Statistics of the Federal Goverment, No.73, str. 173-196.

- Hill, R. (2011). Hedonic Price Indexes for Housing. OECD Statistics Working Papers, 2011/01. OECD Publishing. http://dx.doi.org/10.1787/5kghzxpt6g6f-en.

- Keskin, B. (2008). Hedonic Analysis of Price in the Istanbul Housing Market. International Journal of Strategic Property Management(12), str. 125-138.

- Kunovac et al. (2008). Primjena hedonističke metode za izračunavanje indeksa cijena nekretnina u Hrvatskoj. Istraživanja(I-20). Zagreb: Hrvatska narodna banka.

- Kunovac, D. and Kotarac, K. (2019), Residential Property Prices in Croatia, No 37, Surveys, The Croatian National Bank, Croatia

- Lancaster, K. J. (1966). A New Approach to Consumer Theory. Journal of Political Economy, 74 (2), str. 132-157.

- McDonald, J. F. and McMillen, D. P. (2007). Urban Economics and Real Estate: Theory and Policy. Oxford: Blackwell Publishing.

- Ottensmann, J. R., Payton, S. and Man, J. (2008). Urban Location and Housing Prices within a Hedonic Model. The Journal of Regional Analysis and Policy, 38(1), str. 19-35.

- Rosen, S. (1974). Hedonic Prices and Implicit Markets: Product Differentiation in Pure Competition. The Journal of Political Economy , 82 (1), str. 34-55.

- Sirmans et al. (2006). The Value of Housing Characteristics: A Meta Analysis. The Journal of Real Estate Finance and Economics, 33, str. 215-240.

- Slišković, T. and Tica, J. (2016). Prostorna elastičnost traženih cijena stanova na stambenom tržištu grada zagreba. Ekonomska misao i praksa, (1), 23-44.

- Slišković, T., and Tica, J. (2019). Značaj udaljenosti u hedoničkom modelu određivanja cijena stanova u zagrebu, Ekonomski pregled, 70(5), str. 677-705

- Wooldridge, J. M. (2013). Introductory Econometrics: A Modern Approach (Fifth Edition). South-Western, Cengage Learning.

- Yiu, C. Y. and Tam, C. S. (2004). The estimation of housing price gradients: A comparison of different approaches applied in Hong Kong. International Conference: Adequate\&Affordable Housing for all. Toronto: Centre for Urban and Community Studies, University of Toronto.

- Zietz, J., Zietz, E. N. and Sirmans, G. S. (2008). Determinants of House Prices: A Quantile Regression Approach. Journal of Real Estate Finance and Economics 37(4), str. 317-333. 


\section{Appendix}

Table 9:The estimation of the hedonic model of asked prices in Zagreb

Dependent Variable: LOG(P1)

Method: Least Squares

Date: 08/30/20 Time: 00:15

Sample: 13337

Included observations: 3219

White heteroskedasticity-consistent standard errors \& covariance

\begin{tabular}{crrrr}
\hline \hline Variable & Coefficient & Std. Error & t-Statistic & Prob. \\
\hline C & 7.706989 & 0.017256 & 446.6207 & 0.0000 \\
DCRNOMEREC & -0.192300 & 0.017415 & -11.04192 & 0.0000 \\
DDUBRAVA & -0.377987 & 0.019585 & -19.29949 & 0.0000 \\
DMAKSIMIR & -0.096760 & 0.018481 & -5.235652 & 0.0000 \\
DMEDVESCAK & 0.055555 & 0.023387 & 2.375410 & 0.0176 \\
DNZISTOK & -0.418401 & 0.017952 & -23.30669 & 0.0000 \\
DNZZAPAD & -0.313912 & 0.017758 & -17.67760 & 0.0000 \\
DPESCENICA & -0.251558 & 0.016708 & -15.05572 & 0.0000 \\
DPODSLJEME & -0.146101 & 0.021798 & -6.702402 & 0.0000 \\
DTRESNJEVKAJUG & -0.249923 & 0.016653 & -15.00791 & 0.0000 \\
DTRESNJEVKASJEVER -0.252768 & 0.016343 & -15.46675 & 0.0000 \\
DTRNJE & -0.153101 & 0.019373 & -7.902877 & 0.0000 \\
DZAPAD & -0.368335 & 0.015318 & -24.04536 & 0.0000 \\
DOSTALO & -0.649177 & 0.022750 & -28.53489 & 0.0000 \\
M2 & $-2.91 E-07$ & $3.70 E-07$ & -0.785351 & 0.4323 \\
ROOMS & 0.007505 & 0.003754 & 1.999280 & 0.0457 \\
NEWBUILT & 0.099279 & 0.007989 & 12.42750 & 0.0000 \\
Y2011 & -0.043895 & 0.009690 & -4.529957 & 0.0000 \\
Y2012 & -0.061058 & 0.013966 & -4.371788 & 0.0000 \\
Y2013 & -0.158550 & 0.011234 & -14.11381 & 0.0000 \\
Y2014 & -0.205981 & 0.013525 & -15.22945 & 0.0000 \\
Y2015 & -0.220215 & 0.018519 & -11.89116 & 0.0000 \\
Y2016 & -0.266672 & 0.017488 & -15.24890 & 0.0000 \\
Y2017 & -0.191486 & 0.025517 & -7.504326 & 0.0000 \\
Y2018 & -0.106877 & 0.032034 & -3.336331 & 0.0009 \\
Y2019 & -0.006022 & 0.043527 & -0.138343 & 0.8900 \\
\hline \hline R-squared & 0.436415 & Mean dependent var & 7.449059 \\
Adjusted R-squared & 0.432002 & S.D. dependent var & 0.261592 \\
S.E. of regression & 0.197151 & Akaike info criterion & -0.401652 \\
Sum squared resid & 124.1069 & Schwarz criterion & -0.352569 \\
Log likelihood & 672.4583 & Hannan-Quinn criter. -0.384060 \\
F-statistic & 98.90049 & Durbin-Watson stat & 1.656141 \\
Prob(F-statistic) & 0.000000 & & & \\
\hline \hline & & & & \\
\hline
\end{tabular}

Table 10:The estimation of the hedonic model of realized prices in Zagreb

Dependent Variable: LOG(P2)

Method: Least Squares

Date: 08/27/20 Time: 15:10

Sample: 13337

Included observations: 2165

White heteroskedasticity-consistent standard errors \& covariance

\begin{tabular}{crrrr}
\hline \hline Variable & Coefficient & Std. Error & t-Statistic & Prob. \\
\hline \hline C & 7.623342 & 0.020539 & 371.1680 & 0.0000 \\
DCRNOMEREC & -0.195300 & 0.022228 & -8.786229 & 0.0000 \\
DDUBRAVA & -0.361379 & 0.022825 & -15.83260 & 0.0000 \\
DMAKSIMIR & -0.120617 & 0.023352 & -5.165284 & 0.0000
\end{tabular}




\begin{tabular}{|c|c|c|c|c|}
\hline DMEDVESCAK & 0.003451 & 0.028025 & 0.123140 & 0.9020 \\
\hline DNZISTOK & -0.396463 & 0.021462 & -18.47240 & 0.0000 \\
\hline DNZZAPAD & -0.372616 & 0.023762 & -15.68091 & 0.0000 \\
\hline DPESCENICA & -0.236935 & 0.022053 & -10.74384 & 0.0000 \\
\hline DPODSLJEME & -0.177905 & 0.024790 & -7.176523 & 0.0000 \\
\hline DTRESNJEVKAJUG & -0.213640 & 0.019579 & -10.91145 & 0.0000 \\
\hline TRESNJEVKASJEVER & -0.242985 & 0.019835 & -12.25032 & 0.0000 \\
\hline DTRNJE & -0.146050 & 0.023029 & -6.342120 & 0.0000 \\
\hline DZAPAD & -0.355352 & 0.019206 & -18.50261 & 0.0000 \\
\hline DOSTALO & -0.630402 & 0.039632 & -15.90634 & 0.0000 \\
\hline M2 & $-8.16 \mathrm{E}-07$ & $3.10 \mathrm{E}-07$ & -2.628739 & 0.0086 \\
\hline ROOMS & 0.001888 & 0.004493 & 0.420138 & 0.6744 \\
\hline NEWBUILT & 0.105327 & 0.010633 & 9.905290 & 0.0000 \\
\hline Y2011 & -0.053690 & 0.010777 & -4.9 & 0.0000 \\
\hline Y2012 & -0.058429 & 0.016597 & -3.520490 & 0.0004 \\
\hline Y2013 & -0.192586 & 0.019340 & -9.958040 & 0.0000 \\
\hline Y2014 & -0.198033 & 0.013706 & -14.44818 & 0.0000 \\
\hline Y2015 & -0.195098 & 0.018972 & -10.28352 & 0.0000 \\
\hline Y2016 & -0.217193 & 0.018910 & -11.48542 & 0.0000 \\
\hline Y2017 & -0.118972 & 0.025440 & -4.676569 & 0.0000 \\
\hline Y2018 & -0.050125 & 0.033336 & -1.503644 & 0.1328 \\
\hline Y2019 & 0.045607 & 0.042373 & 1.076311 & 0.2819 \\
\hline ed & 31 & \multicolumn{3}{|c|}{ Mean dependent var 7.347311} \\
\hline djusted R-squared & 0.37 & \multicolumn{3}{|c|}{ S.D. dependent var 0.256927} \\
\hline E. of regression & 0.202640 & \multicolumn{3}{|c|}{ Akaike info criterion -0.342835} \\
\hline Sum squared resid & 87.83365 & \multicolumn{3}{|c|}{ Schwarz criterion $\quad-0.274621$} \\
\hline Log likelihood & 397.1193 & \multicolumn{3}{|c|}{ Hannan-Quinn criter.-0.317889 } \\
\hline F-statistic & 53.59151 & \multirow{2}{*}{\multicolumn{2}{|c|}{ Durbin-Watson stat }} & 1.802330 \\
\hline rob(F-sta & 0.000000 & & & \\
\hline
\end{tabular}

Table 11: The estimation of the hedonic model of asked prices in Middle and South Adriatic Dependent Variable: LOG(P1)

Method: Least Squares

Date: 08/30/20 Time: 01:16

Sample: 1764

Included observations: 760

White heteroskedasticity-consistent standard errors \& covariance

\begin{tabular}{crrrr}
\hline \hline Variable & Coefficient & Std. Error & t-Statistic & Prob. \\
\hline \hline C & 7.727209 & 0.041317 & 187.0236 & 0.0000 \\
DUBNER & 0.128713 & 0.030430 & 4.229751 & 0.0000 \\
SIBKNIN & -0.299180 & 0.033002 & -9.065405 & 0.0000 \\
ZAD & -0.218092 & 0.028281 & -7.711500 & 0.0000 \\
M2 & -0.001484 & 0.000729 & -2.034951 & 0.0422 \\
ROOMS & 0.026734 & 0.017047 & 1.568189 & 0.1173 \\
NEWBUILT & 0.097784 & 0.026151 & 3.739135 & 0.0002 \\
Y2011 & -0.059602 & 0.037582 & -1.585942 & 0.1132 \\
Y2012 & -0.105214 & 0.035846 & -2.935163 & 0.0034 \\
Y2013 & -0.215053 & 0.037513 & -5.732712 & 0.0000 \\
Y2014 & -0.175157 & 0.038453 & -4.555087 & 0.0000 \\
Y2015 & -0.255112 & 0.067164 & -3.798320 & 0.0002 \\
Y2016 & -0.078141 & 0.037563 & -2.080287 & 0.0378 \\
Y2017 & -0.094542 & 0.047668 & -1.983357 & 0.0477 \\
Y2018 & -0.007452 & 0.095247 & -0.078238 & 0.9377 \\
Y2019 & -0.396220 & 0.162145 & -2.443609 & 0.0148 \\
\hline \hline
\end{tabular}




\begin{tabular}{lrll} 
Log likelihood & -75.05883 & Hannan-Quinn criter. 0.277191 \\
F-statistic & 17.67585 & Durbin-Watson stat 1.839914 \\
Prob(F-statistic) & 0.000000 & \\
\hline \hline
\end{tabular}

Table 12: The estimation of the hedonic model of realized prices in Middle and South Adriatic Dependent Variable: LOG(P2)

Method: Least Squares

Date: 08/30/20 Time: 01:21

Sample: 1764

Included observations: 760

\begin{tabular}{crrrr}
\hline \hline Variable & Coefficient & Std. Error & t-Statistic & Prob. \\
\hline C & 7.762938 & 0.071034 & 109.2849 & 0.0000 \\
DUBNER & 0.120050 & 0.042691 & 2.812087 & 0.0051 \\
SIBKNIN & -0.337109 & 0.059068 & -5.707172 & 0.0000 \\
ZAD & -0.315614 & 0.050880 & -6.203091 & 0.0000 \\
M2 & -0.001967 & 0.000884 & -2.225607 & 0.0263 \\
ROOMS & 0.010474 & 0.020836 & 0.502682 & 0.6153 \\
NEWBUILT & 0.074622 & 0.049487 & 1.507921 & 0.1320 \\
Y2011 & -0.030996 & 0.071972 & -0.430670 & 0.6668 \\
Y2012 & -0.178715 & 0.062808 & -2.845430 & 0.0046 \\
Y2013 & -0.258386 & 0.063389 & -4.076213 & 0.0001 \\
Y2014 & -0.221898 & 0.066987 & -3.312550 & 0.0010 \\
Y2015 & -0.262983 & 0.092377 & -2.846845 & 0.0045 \\
Y2016 & -0.077674 & 0.074019 & -1.049381 & 0.2943 \\
Y2017 & -0.083912 & 0.079037 & -1.061678 & 0.2887 \\
Y2018 & -0.009276 & 0.150266 & -0.061731 & 0.9508 \\
Y2019 & -0.379294 & 0.258008 & -1.470088 & 0.1420 \\
\hline \hline R-squared & 0.146218 & Mean dependent var 7.433601 \\
Adjusted R-squared & 0.129004 & S.D. dependent var & 0.466968 \\
S.E. of regression & 0.435808 & Akaike info criterion & 1.197599 \\
Sum squared resid & 141.3070 & Schwarz criterion & 1.295142 \\
Log likelihood & -439.0875 & Hannan-Quinn criter.1.235161 \\
F-statistic & 8.494439 & Durbin-Watson stat & 1.907842 \\
Prob(F-statistic) & 0.000000 & & & \\
\hline \hline & & & & \\
\hline
\end{tabular}

Table 13:The estimation of the hedonic model of asked prices in Istria and North Adriatic Dependent Variable: LOG(P1)

Method: Least Squares

Date: 08/30/20 Time: 01:34

Sample: 1371

Included observations: 371

White heteroskedasticity-consistent standard errors \& covariance

\begin{tabular}{crrrr}
\hline \hline Variable & Coefficient & Std. Error & t-Statistic & Prob. \\
\hline \hline C & 7.638522 & 0.058302 & 131.0168 & 0.0000 \\
LICSENJ & -0.486551 & 0.069408 & -7.010057 & 0.0000 \\
PRIMGOR & 0.023283 & 0.071772 & 0.324407 & 0.7458 \\
M2 & -0.000919 & 0.000506 & -1.815385 & 0.0703 \\
ROOMS & -0.034939 & 0.023296 & -1.499773 & 0.1346 \\
NEWBUILT & 0.175797 & 0.042835 & 4.104006 & 0.0001 \\
Y2011 & 0.010525 & 0.071917 & 0.146351 & 0.8837 \\
Y2012 & -0.242294 & 0.084286 & -2.874677 & 0.0043 \\
Y2013 & -0.309512 & 0.064353 & -4.809625 & 0.0000 \\
Y2014 & -0.161151 & 0.047011 & -3.427920 & 0.0007 \\
Y2015 & -0.245795 & 0.070573 & -3.482869 & 0.0006 \\
Y2016 & -0.376120 & 0.059516 & -6.319657 & 0.0000 \\
Y2017 & -0.089088 & 0.093580 & -0.952002 & 0.3417
\end{tabular}




\begin{tabular}{lrlll}
\multicolumn{1}{c}{ Y2018 } & -0.587553 & 0.091988 & -6.387253 & 0.0000 \\
\multicolumn{1}{c}{ Y2019 } & -0.518679 & 0.189574 & -2.736030 & 0.0065 \\
\hline \hline R-squared & 0.380502 & Mean dependent var & 7.307158 \\
Adjusted R-squared & 0.356140 & S.D. dependent var & 0.387071 \\
S.E. of regression & 0.310590 & Akaike info criterion & 0.538902 \\
Sum squared resid & 34.34185 & Schwarz criterion & 0.697239 \\
Log likelihood & -84.96637 & Hannan-Quinn criter. & 0.601789 \\
F-statistic & 15.61848 & Durbin-Watson stat & 1.775982 \\
Prob(F-statistic) & 0.000000 & & \\
\hline \hline
\end{tabular}

Table 14:The estimation of the hedonic model of realized prices in Istria and North Adriatic Dependent Variable: LOG(P2)

Method: Least Squares

Date: 08/30/20 Time: 01:40

Sample: 1371

Included observations: 371

White heteroskedasticity-consistent standard errors \& covariance

\begin{tabular}{crrrr}
\hline \hline Variable & Coefficient & Std. Error & t-Statistic & Prob. \\
\hline C & 7.594489 & 0.057728 & 131.5572 & 0.0000 \\
LICSENJ & -0.537538 & 0.075508 & -7.118986 & 0.0000 \\
PRIMGOR & 0.021842 & 0.071049 & 0.307414 & 0.7587 \\
M2 & -0.001171 & 0.000619 & -1.890030 & 0.0596 \\
ROOMS & -0.034080 & 0.025415 & -1.340913 & 0.1808 \\
NEWBUILT & 0.156879 & 0.042463 & 3.694459 & 0.0003 \\
Y2011 & 0.021517 & 0.076565 & 0.281024 & 0.7789 \\
Y2012 & -0.225379 & 0.083777 & -2.690214 & 0.0075 \\
Y2013 & -0.362886 & 0.063770 & -5.690564 & 0.0000 \\
Y2014 & -0.182427 & 0.045940 & -3.971019 & 0.0001 \\
Y2015 & -0.254872 & 0.072958 & -3.493426 & 0.0005 \\
Y2016 & -0.363402 & 0.059832 & -6.073653 & 0.0000 \\
Y2017 & -0.036852 & 0.091817 & -0.401366 & 0.6884 \\
Y2018 & -0.496662 & 0.188087 & -2.640598 & 0.0086 \\
Y2019 & -0.484419 & 0.192068 & -2.522127 & 0.0121 \\
\hline \hline R-squared & 0.356532 & Mean dependent var & 7.236753 \\
Adjusted R-squared & 0.331227 & S.D. dependent var & 0.405775 \\
S.E. of regression & 0.331837 & Akaike info criterion & 0.671244 \\
Sum squared resid & 39.20115 & Schwarz criterion & 0.829581 \\
Log likelihood & -109.5157 & Hannan-Quinn criter. & 0.734130 \\
F-statistic & 14.08941 & Durbin-Watson stat & 1.807791 \\
Prob(F-statistic) & 0.000000 & & & \\
\hline \hline
\end{tabular}

Table 15: The estimation of the hedonic model of asked prices in Other region

Dependent Variable: LOG(P1)

Method: Least Squares

Date: 08/30/20 Time: 00:22

Sample: 1322

Included observations: 320

White heteroskedasticity-consistent standard errors \& covariance

\begin{tabular}{ccccc}
\hline \hline Variable & Coefficient & Std. Error & t-Statistic & Prob. \\
\hline \hline C & 7.079404 & 0.059322 & 119.3381 & 0.0000 \\
BJELBIL & -0.172607 & 0.033696 & -5.122433 & 0.0000 \\
KARL & -0.341131 & 0.066252 & -5.149011 & 0.0000 \\
KRAZAG & -0.118851 & 0.050020 & -2.376075 & 0.0181 \\
OSBAR & -0.184531 & 0.046576 & -3.961938 & 0.0001 \\
VAR & -0.062661 & 0.075979 & -0.824708 & 0.4102
\end{tabular}




\begin{tabular}{|c|c|c|c|c|}
\hline VUKSRIJ & -0.197314 & 0.043780 & -4.506940 & 0.0000 \\
\hline M2 & $-3.24 E-06$ & 8.75E-07 & -3.697922 & 0.0003 \\
\hline ROOMS & -0.016824 & 0.011742 & -1.432834 & .1529 \\
\hline JEWBUILT & 0.192023 & 0.024329 & 7.892637 & 0.0000 \\
\hline Y2011 & -0.054623 & 0.051075 & -1.069462 & 0.2857 \\
\hline Y2012 & -0.10 & 0.046619 & -2.255096 & 0.0248 \\
\hline Y2013 & -0.087657 & 0.072341 & -1.211715 & 0.2266 \\
\hline Y2014 & -0.092270 & 0.053239 & -1.733136 & 0.0841 \\
\hline Y2015 & -0.0 & 688 & -1.57 & 0.1159 \\
\hline Y2016 & -0.139759 & 0.055648 & -2.511464 & 0.0125 \\
\hline Y2017 & -0.07 & 0.067500 & -1.07 & 0.2840 \\
\hline Y2018 & -0.0 & 0.05 & -1.78 & 0.0746 \\
\hline Y2019 & -0.0 & 0.051489 & -1.5 & 0.1236 \\
\hline & & \multicolumn{2}{|c|}{ Mean dependent var } & 351771 \\
\hline 1 & & \multicolumn{2}{|c|}{ S.D. dependent var } & 0.220507 \\
\hline f regressic & 0.185626 & \multicolumn{2}{|c|}{ Akaike info criterion } & -0.472627 \\
\hline quared $\mathrm{re}$ & 10.37155 & \multicolumn{2}{|c|}{ Schwarz criterion } & -0.248883 \\
\hline elihood & 94.62038 & \multicolumn{2}{|c|}{ Hannan-Quinn criter } & -0.383282 \\
\hline 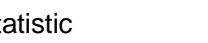 & 8.286175 & \multirow{2}{*}{\multicolumn{2}{|c|}{ Durbin-Watson stat }} & 2.085178 \\
\hline & 0.0000 & & & \\
\hline
\end{tabular}

Table 16: The estimation of the hedonic model of realized prices in Other region

Dependent Variable: LOG(P2)

Method: Least Squares

Date: 08/30/20 Time: 00:23

Sample: 1322

Included observations: 320

White heteroskedasticity-consistent standard errors \& covariance

\begin{tabular}{crrrr}
\hline \hline Variable & Coefficient & Std. Error & t-Statistic & Prob. \\
\hline \hline C & 7.060326 & 0.060474 & 116.7495 & 0.0000 \\
BJELBIL & -0.216732 & 0.035482 & -6.108176 & 0.0000 \\
KARL & -0.381985 & 0.070071 & -5.451402 & 0.0000 \\
KRAZAG & -0.158391 & 0.051006 & -3.105359 & 0.0021 \\
OSBAR & -0.207614 & 0.057037 & -3.640012 & 0.0003 \\
VAR & -0.117173 & 0.085038 & -1.377884 & 0.1693 \\
VUKSRIJ & -0.262617 & 0.048713 & -5.391104 & 0.0000 \\
M2 & $-5.21 \mathrm{E}-06$ & $9.54 \mathrm{E}-07$ & -5.461383 & 0.0000 \\
ROOMS & -0.018994 & 0.013385 & -1.419035 & 0.1569 \\
NEWBUILT & 0.216455 & 0.051607 & 4.194316 & 0.0000 \\
Y2011 & -0.047833 & 0.052088 & -0.918298 & 0.3592 \\
Y2012 & -0.096763 & 0.046638 & -2.074758 & 0.0389 \\
Y2013 & -0.132699 & 0.076197 & -1.741528 & 0.0826 \\
Y2014 & -0.165956 & 0.056088 & -2.958845 & 0.0033 \\
Y2015 & -0.139523 & 0.058903 & -2.368676 & 0.0185 \\
Y2016 & -0.168638 & 0.056503 & -2.984561 & 0.0031 \\
Y2017 & -0.064228 & 0.075762 & -0.847753 & 0.3972 \\
Y2018 & -0.019597 & 0.103286 & -0.189739 & 0.8496 \\
Y2019 & -0.129122 & 0.049095 & -2.630041 & 0.0090 \\
\hline \hline R-squared & 0.327567 & Mean dependent var & 6.772743 \\
Adjusted R-squared & 0.287355 & S.D. dependent var & 0.258701 \\
S.E. of regression & 0.218391 & Akaike info criterion & -0.147522 \\
Sum squared resid & 14.35605 & Schwarz criterion & 0.076222 \\
Log likelihood & 42.60359 & Hannan-Quinn criter. & -0.058177 \\
F-statistic & 8.146026 & Durbin-Watson stat & 2.022786 \\
\hline \hline Prob(-statistic) & 0.000000 & & & \\
\hline \hline & & & & \\
\hline
\end{tabular}

